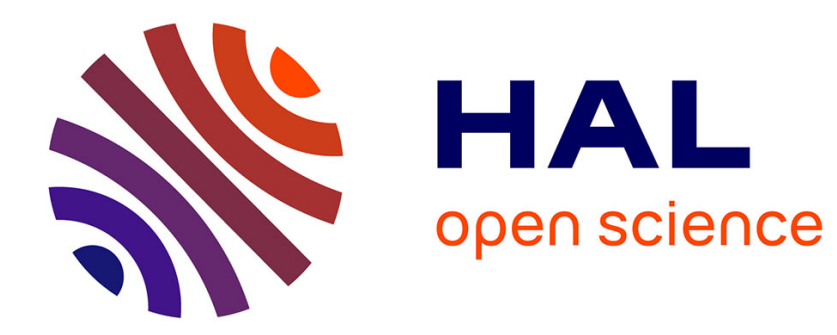

\title{
SPIN-FLUCTUATION THERMOPOWER IN Pd-Ni ALLOYS
}

\author{
W. Calwell, D. Greig
}

\section{To cite this version:}

W. Calwell, D. Greig. SPIN-FLUCTUATION THERMOPOWER IN Pd-Ni ALLOYS. Journal de Physique Colloques, 1978, 39 (C6), pp.C6-865-C6-866. 10.1051/jphyscol:19786385 . jpa-00217853

\section{HAL Id: jpa-00217853 https://hal.science/jpa-00217853}

Submitted on 1 Jan 1978

HAL is a multi-disciplinary open access archive for the deposit and dissemination of scientific research documents, whether they are published or not. The documents may come from teaching and research institutions in France or abroad, or from public or private research centers.
L'archive ouverte pluridisciplinaire HAL, est destinée au dépôt et à la diffusion de documents scientifiques de niveau recherche, publiés ou non, émanant des établissements d'enseignement et de recherche français ou étrangers, des laboratoires publics ou privés. 


\section{SPIN-FLUCTUATION THERMOPOWER IN Pd-Ni ALLOYS}

W. Calwe11 and D. Greig,

Physics Department, University of Leeds, Leeds LS2 9JT, U.K.

Résumé.- Cette étude expêrimentale sur le pouvoir thermoêlectrique, S, de certains alliages

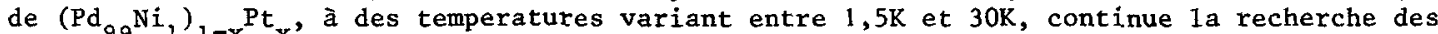
hautes valeurs anormales de $\mathrm{S}$ à $\sim 20 \mathrm{~K}$ dans les alliages paramagnétiques de $\mathrm{Pd}-\mathrm{Ni}$.

On trouve que $1 a$ très haute valeur (négative) de $S$ disparaît pratiquement, au fur et à mesure que la valeur de $x$ passe de 0 à $1 \%$. Cela $s^{\top}$ explique tout simplement par le fait que le composant de $\mathrm{S}$ provenant de la diffusion électronique se modifie parce que $\mathrm{Ni}$ se remplace comme impureté prédominante par Pt. Par conséquent les résultats obtenus à la suite de cette étude vont à 1 'encontre de 1 a notion du phénomène dit "paramagnon drag".

Abstract. - The anomalous peaks at $\sim 20 \mathrm{~K}$ in the thermopower, $\mathrm{S}$, of paramagnetic $\mathrm{Pd}-\mathrm{Ni}$ alloys have been investigated further by an experimental study of $\mathrm{S}$ in dilute ( $\left.\mathrm{Pd}_{\mathrm{Og}_{\mathrm{g}}} \mathrm{Ni}_{1}\right)_{\mathrm{I}} \mathrm{Pt}$ alloys in the temperature $1.5 \mathrm{~K}$ to $30 \mathrm{~K}$. It is found that as $x$ is increased from 0 to $1 \%$ the pronounced (negative) peak in $\mathrm{S}$ virtually disappears. This result con be simply explained by a change in the diffusion component of $S$ as the dominant electron-scatterer changes from Ni to Pt, and weighs heavily against the idea of "paramagnon drag".

Although the low temperature thermopower, $S$, of dilute $\mathrm{Pd}-\mathrm{Ni}$ alloys was first measured by Foiles and Schindler $/ 1 /$ over 10 years ago, the most outstanding feature of the measurements has never been understood. This is the large (negative) minimum in $S$ at about $20 \mathrm{~K}$ in all paramagnetic samples. Foiles and Schindler recognized that the qualitative features of these peaks were quite different to those in local moment (Kondo) alloys. Whereas in the latter case the extrema at low temperatures tend to decrease and broaden as the concentration of solute is increased, in $\mathrm{Pd}-\mathrm{Ni}$ the peaks remain sharp and increase markedly in magnitude as the $\mathrm{Ni}$ content is increased from 0.5 to $1.66 \%$.

Sharp peaks of this type have also been found in Ir-Fe /2/ and Rh-Fe alloys /3/. Although there are some differences in detail between the results in the three alloy series -- in Ir-Fe the sign of the peak is positive -- there are sufficient similarities for the 3 systems to be considered as equivalent examples of nearly magnetic alloys. In every case the peak in $S$ occurs at a temperature, $T_{P}$, wich is of the order of the spin-fluctuation temperature, $\mathrm{T}_{\text {sf }}$, deduced from resistivity measurements.

This experimental evidence has been summarized by Kaiser /4/ who argued that any explanation of the peaks in terms of an enhanced diffusion thermopower by electron-paramagnon scattering is most unlikely. Instead he has proposed that, by analogy with phonon-drag, the anomalies are due to paramagnon drag resulting from the equilibrium distribution of spin-fluctuations along the temperature gradient.

Kaiser has suggested that this proposal should bo tested by measuring the temperature dependence of $S$ in a series of $\left(\mathrm{Pd}_{99} \mathrm{~N}_{1}\right)_{1-x} \mathrm{Pt}_{x}$ alloys; that is alloys we had previously used /5/ to investigate changes on alloying in $A$, the coefficient of the $\mathrm{T}^{2}$ component of electrical resistivity. The result of that experiment was that as $x$ was increased from 0 to $2 \%$, the impurity (residua1) resistivity increased by a factor of 6 but the unusually high value of $A$ remained unchanged. We infer that although $\mathrm{Pt}$ has replaced $\mathrm{Ni}$ as the dominant impurity scatterer, the paramagnon spectrum is still as in $\mathrm{Pd}-\mathrm{Ni}$. Consequently measurements of $\mathrm{S}$ in the ternary alloys could be used to distinguish between a diffusion effect -- where the peak in $S$ would disappear as the characteristic thermopower changed from that of $\mathrm{Pd}-\mathrm{Ni}$ (+ve) to that of $\mathrm{pd}-\mathrm{Pt}$ (-ve) -- and a "drag" effect where the peak would be sustained.

We have measured $\mathrm{S}$ between about $1.5 \mathrm{~K}$ and $30 \mathrm{~K}$ on Pd-Ni and 3 selected ternary alloys by the usual 
equilibrium method, using $\underline{A g}+2.5$ at. $\%$ Au as the reference material. The results are shown in figure 1 .

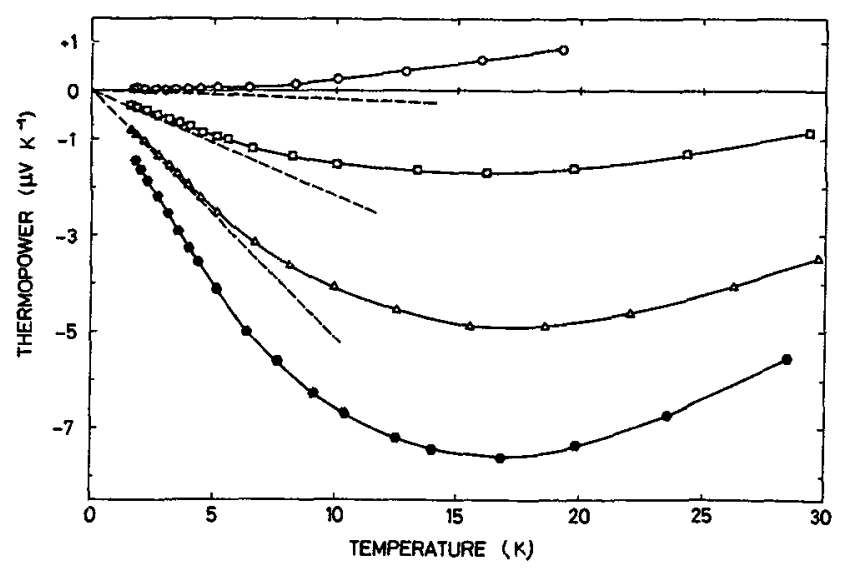

Fig. 1 : Temperature dependence of thermopower in $(\mathrm{Pd}-\mathrm{Ni}) \mathrm{Pt}$ alloys.,$\left(\mathrm{Pd}_{9 \mathrm{Ni}}\right) ; \Delta,\left(\mathrm{Pd}_{9 \mathrm{~N}} \mathrm{Ni}\right)+$ 0.2 at. \%Pt; $\square,\left(\mathrm{Pd}_{9 \mathrm{Ni}^{9}}\right)^{\mathrm{N}}+1$ at. \% $\mathrm{Pt} ; \mathrm{O}$, $(\mathrm{Pd}(\mathrm{Ni})+10$ at. $\% \mathrm{Pt}$. The lines represent the 9 values of $S$ for the ternary alloys calculated from equation (1).

The measurements have a relative accuracy of about $2 \%$ with a further uncertainty from the calibration of the thermopower of reference alloy of $\pm 15 \mu \mathrm{V}$ $\mathrm{K}^{-1}$ above $\sim 8 \mathrm{~K}^{\text {and }} \pm 5 \mu \mathrm{V} \mathrm{K}-1$ below that temperature. In terms of this small uncertainty the results on Pd-Ni are in excellent agreement with those of Foiles and Schindler $/ 1 /$.

It is immediately apparent that, with the addition of about $1 \% \mathrm{Pt}$ to the basic Pd-Ni, the peak at $\sim 20 \mathrm{~K}$ has virtually disappeared. The marked reduction in the value of $|S| / T$ at the lowest temperatures can be simply explained by the change of weighting of the impurity thermopower according to the Nordheim-Gorter formula

$$
S=\frac{p_{0}(N i) S(N i)+p_{0}(P t) S(P t)}{\rho_{0}(N i)+p_{0}(P t)}
$$

where $\dot{p}_{0}(\mathrm{Ni}), p_{0}(P t), S(\mathrm{Ni})$ and $S(p t)$ represent the residual resistivities and impurity thermopowers of the binary alloys $\underline{\mathrm{Pd}}-\mathrm{Ni}$ and $\mathrm{Pd}-\mathrm{Pt}$. From values of these parameters taken from the measurements on $\mathrm{PA}-\mathrm{Ni}$ and from our previous publications $/ 5,6 /$ we have calculated the the diffusion thermopower at the lowest temperatures for the three ternary alloys as shown in figure 1 . It is clear that the measurements can be completely explained in this way and that the idea of paramagnon drag is not required. The experiment does not, of course, indicate why the diffusion thermopower in $\underline{P d}-\mathrm{Ni}$ is so very high, but, by excluding an alternative explanation, points clearly to the need for a detailed calculation of the value of $s$ resulting from electron-paramagnon scattering.

\section{Acknowledgements.- We are greatly indebted}

to Dr. A. Kaiser for drawing our attention to this problem and to SRC for financial support. Mr Calwell also wishes to thank the Department of Education, Northern Ireland for providing a Postgraduate Studenship.

\section{References}

$/ 1 /$ Foiles, C.L. and Schindler, A.I., Phys. Lett. 26A (1968) 154.

12/ Touger, J.S. and Sarachik, M.P., Solid State Commun. 17 (1975) 1389.

/3/ Graebnex, J.E., Rubin, J.J., Schutz, R.J., Hsu, F.S.L., and Reed, W.A., Magnetism and Magnetic Materials, 1974, Eds. Graham, C.J., Jr. Lander, G.H., and Rhyne, J.J. (American Inst. of Physics, New York) 24 (1975) 445.

14/ Kaiser, A.B., Magnetism and Magnetic Materials, 1975, Eds. Becker, J.J., Lander, G.H., and Rhyne, J.J. (American Inst. of Physics, New York) $\quad 29$ (1976) 364.

/5/ Greid, D. and Rowlands, J.A., J.Phys.F : Metal Phys.4 (1974) 232.

/6/ Blood, P. and Geig, D., J.Phys.F : Metal Phys. $\underline{2}$ (1972) 79. 